\title{
Development of a Model with Critical Factors of Success, Predominant in Implementation of a Membrane System in the Wastewater Treatment-Review of the Case Study of a Dairy Industry
}

\author{
Julio Americo Faitão*, Juliana Steffens, Clarice Steffens, Rogério M. Dallago, Adriana T. Storti, \\ Airton C. Bortoluzzi
}

Gestão e Negócios, Instituto Federal de Educação, Ciência e Tecnologia do Rio Grande do Sul, Erechim, Brazil

Email: *julio.faitao@erechim.ifrs.edu.br

How to cite this paper: Faitão, J.A., Steffens, J., Steffens, C., Dallago, R.M., Storti, A.T. and Bortoluzzi, A.C. (2018) Development of a Model with Critical Factors of Success, Predominant in Implementation of a Membrane System in the Wastewater Treatment-Review of the Case Study of a Dairy Industry. Technology and Investment, 9, 117-135.

https://doi.org/10.4236/ti.2018.92009

Received: April 8, 2018

Accepted: May 28, 2018

Published: May 31, 2018

Copyright $\odot 2018$ by authors and Scientific Research Publishing Inc. This work is licensed under the Creative Commons Attribution International License (CC BY 4.0).

http://creativecommons.org/licenses/by/4.0/

\section{cC) (7) Open Access}

\begin{abstract}
The objective of this study was to identify the critical success factors (CSFs) that predict, in a specific niche, the dairy sector in Brazil and later monitor their behaviors behavior when applied together with the project management activity, along with a case study where the extrapolation of the implementation of wastewater treatment by the combined membrane system was carried out. In order to develop the case, the hypothetical-deductive method was adopted and later the content analysis was carried out through the Sphinx Lexical (qualitative analysis) computer system, data clusters and quantitative data validation was performed with SPSS Statistic, allowing to understand CSF of classification. In applying this methodology, after grouping factors in the company, one can verify the existence of implicit relationships of the FCSs, impacting mainly on the organizational aspects, especially related to the effective communication and the need for managerial support in the decision making as the most representative and factors related to risk planning and analysis. As for the explicit impact of the factors with the organization, one can verify the predominance of cost factors, and the possibility of reusing water.
\end{abstract}

\section{Keywords}

Wastewater Treatment, Critical Success Factors, Project, Reuse 


\section{Introduction}

The urgency in improving the management of water resources by the regulatory entities and the conscious and intelligent consumption is about issues that guide the main discussions around the world. The waste and the reckless use of water resources take to a water shortage for human consumption, both by increasing water demand because of the population explosion and economic growth, and the increasing deterioration of the quality of this finite resource, caused by indiscriminate pollution.

Due to this problem of water scarcity, Annecchini (2005) [1] found that there is an increasingly concern in consumer awareness, appropriate treatment and reuse of it. Among the industries, food industries have been consuming large amounts of water and among them there is the dairy industry. The effluents generated by this industry field come from water of processes as well as equipment washing, tanks, etc. that have a highly polluting load. These effluents are usually treated by physicochemical processes such as decantation, filtration, coagulation/flotation and biological processes that operate through microbiological degradation using ponds, but require large areas to achieve the efficiency required for the treatment, which is hardly achieved in subtropical regions due to low temperatures (SMITHERS, 2008 [2]; Hamerski, (2012) [3]. In this sense, alternative means of treatment of these effluents have been studied, including the possibility of reuse, such as the use of membrane separation processes (MSP).

Considering the efficacy of the MSP use, it is necessary to identify critical success factors (CSFs) in implementation of these processes for effluent treatments of dairy industries. CSFs are key points that when well executed, define and guarantee the development and growth of a company and its business, achieving its goals, such as the use of new alternatives for wastewater treatment. According to Olson and $\mathrm{Wu}$ (2010) [4], the possibility to follow up the evolution of projects that include feasibility, market, etc., can be designed and monitored by their potential key success indicators, which enable the monitoring of faults, structural weaknesses and structuring scenarios by organizations.

Basu (2014) [5] emphasizes the importance of CSFs selection with the assertiveness of the objectives and the selection of monitoring requirements for assessing them. Thus, the performance data forms are identified as metrics so that each part of the projects can be monitored as for performance and compare them with the established. Frigo and Anderson (2009) [6] corroborate the need to identify and monitor risks, when they say that in effective management we should seek to control or even eliminate the risks, in order to increase the benefits and to prevent speculation, which may adversely affect the cost, time, quality and performance of the organizational system.

Following in the demonstration of the CSFs monitoring relevance, Tarapanoff and Gregolin (2002) [7] in 2002 already indicated that the CSFs had growing importance among the formatting techniques of competitive intelligence and are being used in the formulation of strategies in organizations that work in trans- 
formation environments. They are a few issues that when identified will provide positive results for the organization.

Regarding the setting of dairy industries, one can identify a growth in demand for products, which also leads to an increase in consumption, a need to expand studies on the sector. The industry in question currently uses in order to monitor the market, both private studies and studies arising from dairy unions, as SINDILAT and the union of industries, as well as IBGE database, among other official external sources, in order to identify opportunities and threats existing in the sector. However, for identifying strengths and weaknesses, industries need to conduct an internal diagnosis, which may well see the difficulties that they have to meet their objectives, as well as how prepared and strengthened they are to face the market. These results working in an aggregated manner will demonstrate the direction in which the industry must follow and thus, the most important features are identified to be observed and monitored in order to obtain assertiveness in action to be taken, such as skills development, development of new products or processes, geographical location of delivery, costs, technological innovations, among others, and which are termed as critical success factors (CSFs), to the success of operations.

\subsection{Water Scenario}

Population growth, industrialization, expansion of agriculture and climate changes are presented as phenomena inherent to the development, and thus for not having their proper care, result in degradation processes and scarcity of water resources. With according to Koncagül et al. (2017) [8] global freshwater extractions can be estimated to be $3928 \mathrm{~km}^{3}$ per year, and of this value, approximately $44 \%$ (1716 $\mathrm{km}^{3}$ per year) are consumed mainly in agriculture, through evaporation that occurs in irrigated areas. The remaining $56 \%\left(2212 \mathrm{~km}^{3}\right.$ per year) return to the environment as wastewater, in the form of urban, industrial effluents and agricultural drainage water.

According to Gollin, et al. (2014) [9] the main uses of water are for domestic use, irrigation, industrial use and power generation, consequently with population growth, there is also an increase in water consumption. The United Nations (UN) in its 2016 report confirms the urgency of the paradigm changes in global water consumption, displaying a view that for the next 30 years an increase in global water demand of $55 \%$ will occur, mainly due to the increasing demand from industrial sector, thermoelectric power generation systems and home users. UN also points out that industry is still playing a key role in the global water consumption, foreseeing for 2050, an increase of $400 \%$ of the demand by the manufacturing industry. Agriculture by 2050 will need to produce globally $60 \%$ more food, alarming the scenario for the coming years. The report also highlights technological developments in urban water production and waste management that will contribute to the reduction in water withdrawals and in waste production. Thus, it points out that there is a need for rapid mobilization to the 
development of combined technologies with an increase in public awareness about water scarcity.

\subsection{Effluent Treatment of Dairy Industry}

Milk manufacturing process presents generation of many by-products and waste, however, the liquid effluents are considered as major contributors of pollution of dairy industries and can be observed in the following points of generation of industrial effluents: washing and cleaning products remaining in trucks, drums, tanks, machinery and equipment directly involved in the production; spills, leaks, faulty operation of equipment and overflow tanks; losses in the process, such as "start" and "stop" operations of the pasteurizer and overflow of products, drag of products in steaming (condensate and powder milk) and those resulting from the arrangement of conditioners at the beginning of the packaging process ; disposal products, such as sour milk or whey; milk pasteurization, which uses alkaline and acid solutions very focused on pasteurizer cleaning; thorough cleaning of equipment and floor of the production room, by using large amounts of water, resulting in a large volume of wastewater with large amount of solids, clots, detergents and disinfectants. This step occurs at the end of the day.

According to Balannec et al. (2008) [10], about $10 \mathrm{~L}$ of effluent for each $1 \mathrm{~L}$ of processed milk are generated in the dairy industry, which had already been identified by Strydom et al. (1997) [11], the relation between liquid effluent flow rate and the water flow rate consumed by dairy is between 0.75 and 0.95 , which shows and shows a high amount of effluent generation and the need for water consumption. Wastewater of different dairy industries have similar characteristics because it is the same source, but Table 1 shows the characteristics of medium dairy industries with and without cheese production lines.

Table 2 shows the physicochemical characteristics of raw wastewater from dairy industries, as well as the emission standards set by law.

Conventional treatment of dairy industry effluent involves the use of primary treatment for removing oil and fat, as well as solids of effluent. In the secondary treatment happens the removal of organic matter and nutrients (nitrogen and phosphorus) and in the tertiary treatment occurs polishing of effluent treatment. Britz et al., 2008 [17], reports that as a pretreatment of dairy effluents, a grid is used for removing coarse solids, such as packaging waste, small stones fragments and milk clots. In industries where the wastewater is generated only at times of the day, equalization tanks are also adopted. In these tanks $\mathrm{pH}$ correction, can also occur, as seen from Table 3 .

Primary treatment with decantation, filtration, coagulation/flocculation with compressed or dissolved air BRAILE (1993) [19]; BRITZ et al. (2008) [17] happens afterwards. This step needs special care and strict control of operating conditions to ensure fat removal efficiency, due to high fat levels (above $150 \mathrm{mg} / \mathrm{L}$ ) cause various problems in biological treatment systems (PEIRANO, 1995) [20]. 
Table 1. Wastewater characteristics of dairy industry.

\begin{tabular}{ccccccc}
\hline Waste Type & COD & BOD & P H & TSS & TS & References \\
\hline Milk \& Dairy Products factory & $10,251.2$ & 4840.6 & 8.34 & 5802.6 & & Oneț Cristian, 2010 \\
Dairy efluente & $1900-2700$ & $1200-1800$ & $7.2-8.8$ & $500-740$ & $900-1350$ & 0 U. B. Deshannavar, et al. 2012 \\
Arab Dairy Factory & $3383 \pm 1345$ & $1941 \pm 864$ & $7.9 \pm 1.2$ & $831 \pm 392$ & & A. Tawfik et al., 2007 \\
Dairy waste water & $2500-3000$ & $1300-1600$ & $7.2-7.5$ & $72,000-80,000$ & $8000-10,000$ & Javed Iqbal Qazi et al. \\
Aavin dairy industry washwater & $2500-3300$ & & $6.4-7.1$ & $1630-730$ & $1300-1400$ & Sathyamoorthy G.L, et al., 2012 \\
Dairy industry wastewater & 2100 & 1040 & $7-8$ & 1200 & 2500 & A. Arumugam \\
\hline
\end{tabular}

Source: Dairy industry wastewater sources, characteristics e its effects on environment, Bharati and Shinkar (2013 p. 1613) [12].

Table 2. Physicochemical characteristics of raw wastewater from dairy industries found by some authors and standard releases specified in legislation.

\begin{tabular}{|c|c|c|c|c|c|}
\hline PARAMETERS & ANDRADE et al. (2014) & BRIÃO et al. (2007) & SILVA (2006) & CONSEMA (2006) & CONAMA (2011) \\
\hline Color (mg Pt Co L ${ }^{-1}$ ) & 2316.6 & - & - & $\begin{array}{l}\text { It should not confer color } \\
\text { change to water body receptor }\end{array}$ & - \\
\hline Turbidity (FAU) & - & 2180.0 & - & - & - \\
\hline $\operatorname{COD}\left(\mathrm{mg} \mathrm{L}^{-1}\right)$ & 2937.6 & 3405.1 & $2120-4287$ & $150-400$ & - \\
\hline $\begin{array}{c}\text { BOD5 } \\
\left(\mathrm{mg} \mathrm{L}^{-1}\right)\end{array}$ & - & & $496-1712$ & $40-180$ & $\begin{array}{c}\text { Least removal of } \\
60 \%\end{array}$ \\
\hline $\operatorname{Protein}\left(\mathrm{mg} \mathrm{L}^{-1}\right)$ & - & 477.0 & - & - & - \\
\hline Lactose $\left(\mathrm{mg} \mathrm{L}^{-1}\right)$ & - & 914.8 & - & - & - \\
\hline Animals (mg L ${ }^{-1}$ ) & - & 879.0 & $22.1-806$ & 30 & 50 \\
\hline Suspended Solids ( $\mathrm{mg} \mathrm{L}^{-1}$ ) & - & 844.0 & $230-780$ & $50-180$ & - \\
\hline $\mathrm{KTN}\left(\mathrm{mg} \mathrm{L}^{-1}\right)$ & 49.8 & - & - & $10-20$ & 20 \\
\hline $\mathrm{pH}$ & - & - & $4.9-11.28$ & $6.0-9.0$ & $5.0-9.0$ \\
\hline
\end{tabular}

Source: Adapted from Andrade et al. (2014) [13], Brião (2007) [14]; Silva (2006), Rio Grande do Sul (2006) [15] and Brazil (2011) [16].

Table 3. Average concentrations and removal efficiencies of organic matter.

\begin{tabular}{cccc}
\hline Parameters & Influx & Effluent & Removal\% \\
\hline Calculated BOD $\left(\mathrm{mg} \mathrm{L}^{-1} \mathrm{O}_{2}\right)$ & 3240.00 & 91.06 & 97.17 \\
Real BOD $\left(\mathrm{mg} \mathrm{L}^{-1} \mathrm{O}_{2}\right)$ & 1251.00 & 149.83 & 88.02 \\
COD (mg L $\left.{ }^{-1} \mathrm{O}_{2}\right)$ & 2568.8 & 165.13 & 93.59 \\
Total Solids $\left(\mathrm{mg} \mathrm{L}^{-1}\right)$ & 427.0 & 68.9 & 83.84 \\
Sedimented Solids $\left(\mathrm{mg} \mathrm{L}^{-1}\right)$ & 0.5 & 0.1 & 80.00
\end{tabular}

Source: Magno and Oliveira (2009) [18].

As a secondary treatment, because they are wastewater with high concentration of biodegradable organic matter, biological treatment is the most used. Thus, aerobic processes are the most used, such as activated sludge, biological filters and aerated ponds (PEIRANO, 1995 [20]; BRAILE, 1993 [19]), although the use of anaerobic processes are increasing (CAMMAROTA; FREIRE, 2006 
[21]).

Braille, and Cavalcanti (1993) [19] reported BOD removal efficiencies in activated sludge systems for dairy effluents between $73 \%$ and $99 \%$, and that the hydraulic retention time is 7 hours. In this system, there are problems such as difficulties in starting, foaming, low sedimentation of sludge and generation of large amounts of excess sludge (MACHADO, et al., 2002) [22].

Aerated ponds generally operate with hydraulic retention time from 3 to 6 days, although the load variation and some degree of effluent toxicity may be minimized by the large volume of the pond. In this type of treatment, the release parameters of the effluent are not always met, besides problems with losses of toxic substances by volatilization, odors, proliferation of insects, plant growth, high concentration of algae and large areas for ponds construction. There is also need for periodic removal of the pond bottom sludge or the installation of a secondary sedimentation tank to enhance the clarity of the final effluent. (MORAIS, 2005) [23].

Physicochemical treatments for dairy effluent, such as membrane separation processes using microfiltration membranes, ultrafiltration, nanofiltration and reverse osmosis (DAUFIN G. et al., 2008 [24]; BORTOLUZZI, 2016 [25]) have also been used as tertiary treatment, aiming to produce effluent quality that not only meets the discharge standards, but also allow reuse.

The combined membrane technology to biological processes has been achieving good results in the fields of wastewater treatment, as claimed by Reis and Zydney (2001) [26]. A high level of wastewater treatment can be accomplished without the conventional arrangement of the aeration tank, decantation and filtration to produce a reasonable standard of tertiary effluent.

\subsection{Membrane Separation Processes}

The separation membrane processes emerged in the 1970s, in order to complete the classical separation processes such as distillation, filtration, adsorption, ion exchange, centrifugation, solvent extraction, crystallization, among others. This new class of processes started using synthetic membranes as selective barrier. Synthetic membranes have emerged as an attempt to imitate natural membranes, particularly regarding their unique characteristics of selectivity and permeability. Generally, a membrane is a barrier that separates two phases and limits total or partial transport of one or several chemical species present in the phases (Habert et al., 2006) [27].

Membrane separation processes (MSP) amplify the conventional filter setting for separations where the solutes are dissolved in liquid or gas stream. These processes have operations for separation, concentration or purification of substances. The main MSPs include microfiltration (MF), ultrafiltration (UF), nanofiltration (NF), reverse osmosis (RO) (DEKKER et al., 2003) [28]. In this type of separation process two streams are generated, one called "concentrate", richer in species and less permeable, and other, called "permeate", more diluted in rela- 
tion to the same kind as illustrated in Figure 1.

These processes (MSP) using gradient of pressure as the driving force are classified according to the size of the particles or molecules to be separated. The smaller the size of these species, the smaller should be pore size of the membrane and hence higher must be the applied pressure difference, Borges et al. (1997) [29]. Figure 2 presents the differences among membrane separation processes (GIRARD and FUKUMOTO, 2000) [30].

Membrane Separation Processes are based on the principle that a mixture may be fractioned partially by passage through a porous structure, (SCHNEIDER and TSUTIYA 2001) [31] allowing the fractionation of solutes dissolved in liquid streams and separation of gas mixtures, which happens by the affinity degree of certain components with the membrane. The elements with higher affinity

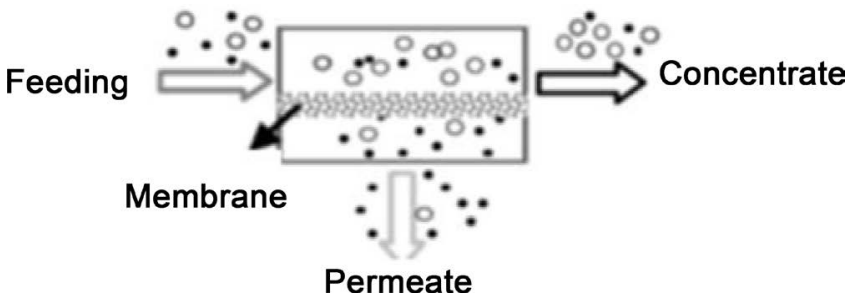

Source: Decker et al. (2003).

Figure 1. Schematic representation of a membrane system.

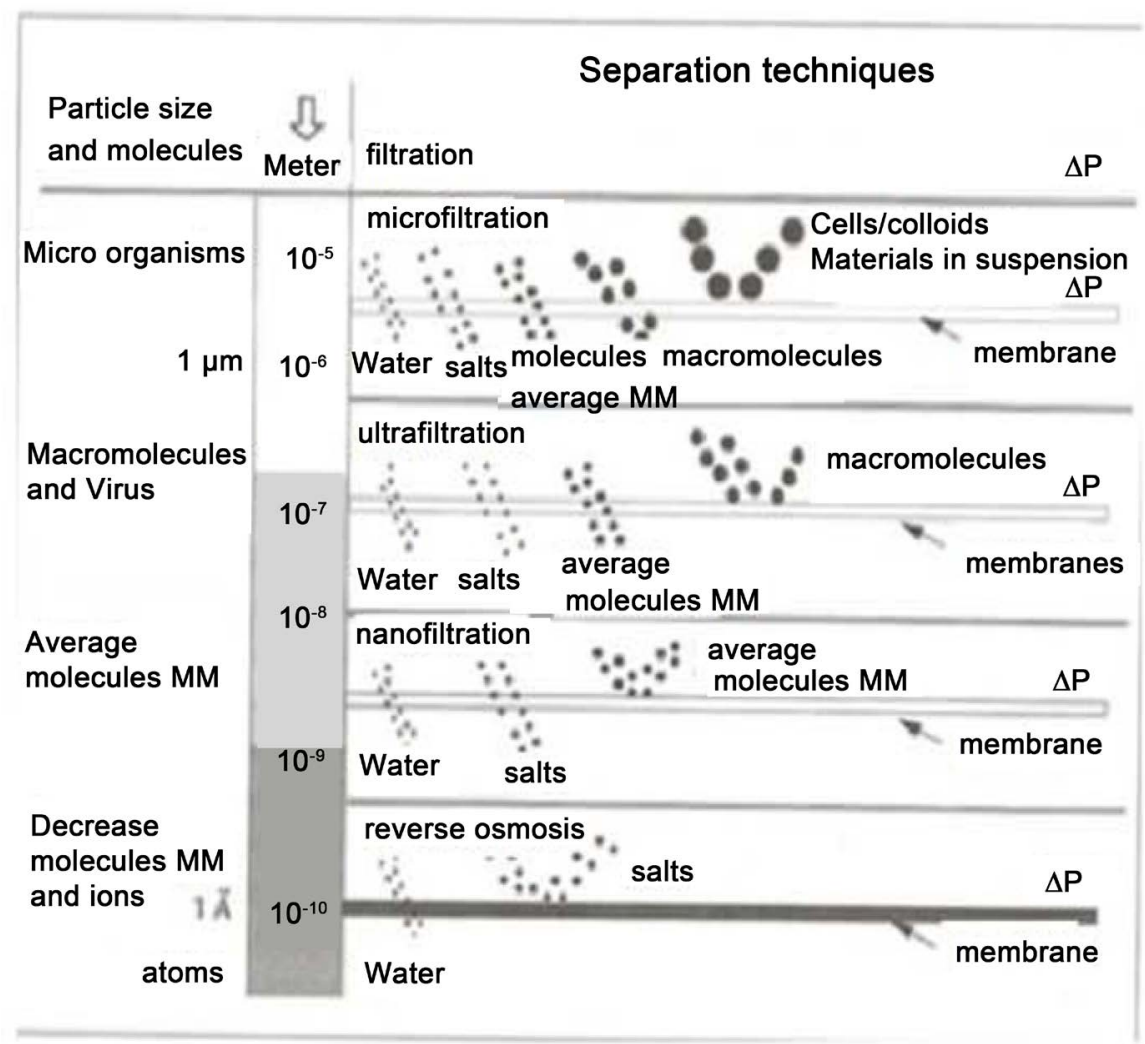

Source: Girard and Fukumoto (2000)

Figure 2. Main characteristics of processes that use pressure difference as driving force. 
permeate it and pass under the name permeate. The stream that does not permeate the membrane is called retained, nonpermeate or concentrate.

Figure 3 [32] shows selective capabilities of MSP that use pressure as driving force and can be applied according to the approximate size of particles, except for membrane $\mathrm{NF}$ and $\mathrm{RO}$, which separate solutes, primarily by diffusive processes. Besides the dimensions of the particles in $\mu \mathrm{m}$ and $\mathrm{nm}$, it is also used molecular weight cut off (MWCO from English molecular weight cut-off, given in $\mathrm{g} \mathrm{mol}$ or $\mathrm{Da}$ ), and $1 \mu \mathrm{m}$ is equivalent to $7500 \mathrm{kDa}$.

Microfiltration membranes (MF) are made up of pores between 0.1 and 1.0 $\mu \mathrm{m}$ indicated for retaining of materials in suspension and emulsion, permeating the entire solvent and soluble material, wherein the separation mechanism is by size exclusion of particles in relation to the pore size of the membrane. According to the pore size, the pressure applied to transportation is small, around $3 \mathrm{bar}$ (Habert, A.C. et al., 2006) [27].

Ultrafiltration membranes (UF) have pore sizes from 1 to $100 \mathrm{~nm}$. They are used for the separation and concentration of macromolecules and colloidal particles Habert et al. (2006) [27], and the applied pressure is usually 1 and 7 bar Coutinho, et al. (2009) [33]. In the process of nanofiltration (NF), membranes have pore size around $1 \mathrm{~nm}$. The applied pressure is greater than UF.

Reverse osmosis processes have as determining of their selectivity the differences in coefficients of diffusion components through the membrane and its affinity with respect to the membrane material, consisting of an additional factor for separation (PABBY et al., 2009 [34] and Mulder 2000 [35]). However, the solvent flux is also proportional to the applied pressure, being the primary parameter influencing the chemical potential (Habert et al., 2006) [27].

The performance of the membranes is measured in terms of permeate flux given by the ratio between the permeate flow and the filter membrane area. Several factors can influence this performance, such as polarization by concentration and fouling, which are the main, and therefore need to be considered in the process so that it is viable. The polarization by concentration is related to the retention of solutes and the formation of a layer on the membrane interface with a

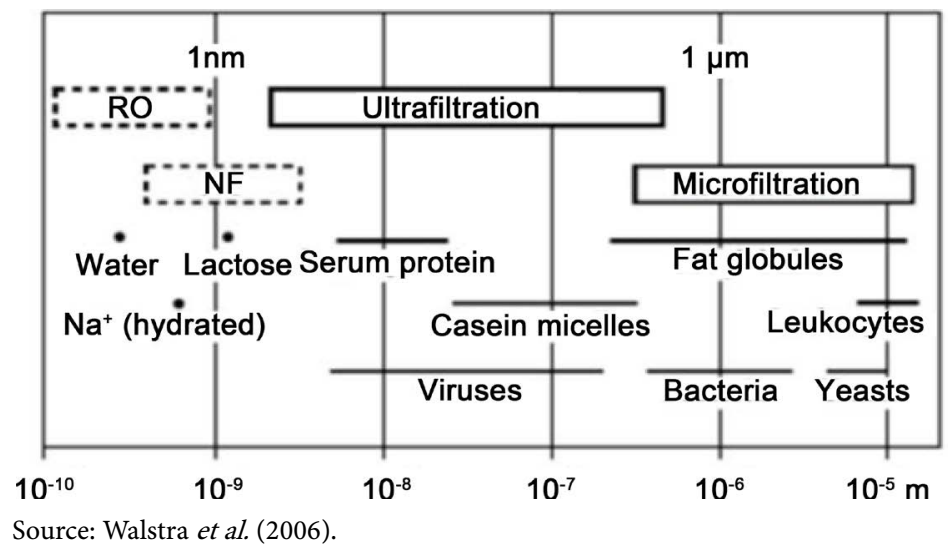

Figure 3. MSP and their selective abilities to approximate size of particles. 
high concentration of solutes, Macedo et al. (2011) [36]. Fouling is caused by the deposition and retention of particles, colloids, emulsions, suspensions, macromolecules, salts, among others, under or within the pores of the membrane (Mulder, 2000) [35]. If these factors are not controlled, the permeate flow can be reduced to the point that prevents the separation process.

Thus, this study aimed at identifying the most relevant critical success factors to dairy industries, correlating critical factors to the analysis of wastewater treatment projects, and identifying through critical factors the feasibility of wastewater treatment projects.

\section{Material and Methods}

\section{Critical Success Factors}

In a world, increasingly complex, envisioned and presented by Naisbitt (1999) [37], organizations have been dedicating themselves to information access relevant to their vital functions and to a specific focus. The need for effective management techniques is seen as a universal goal among the business communities, which seek to guarantee the achievement of pre-defined objectives drawn up by them for decades.

One among the many existing techniques, which aim to assist the accomplishment of plans, goals, investment actions and determine more precisely what are the information needed to be monitored to provide greater reliability to their projects, is the technique named "Critical Success Factors" (CSFs), which was introduced to organizational communities in an HBR (Hardware Business Review) article titled Chief Executives Need to Define their own Data, developed by Daniel (1961) [38] and later refined and popularized by Rockart (1982) [39].

By trying to meet this flexibility, CSFs are presented as a technique that is growing in the organizational environment, as shown by Gates (2010) [40]. This visibility growth is justified because it is an easy upgrade technique and follows business needs, providing identification and monitoring of starting activities in which favorable results are absolutely necessary for an organization to achieve the goals set. With this technique, it is possible to identify and classify the activities called critical, and thus providing managers appropriate information that allow them to determine whether the actions are structured or not according to the plan.

The application of the critical success factor technique (CSF) as shown by Finney and Corbett (2007) [41], makes it possible to identify actions that should be monitored, however, the way in which they will be monitored varies with the organization structure and may be implemented by a system, program, project, process, or even a spreadsheet measurement, but the result should enable the monitoring of the achievement of the proposed actions.

To Howell (2010) [42], the critical success factors (CSFs) may be used at all levels of an organization, from management by the operating areas, aiming internal improvement initiatives such as the need for increased efficiency or im- 
provements derived from forces of external changes, such as technology, legislation or level of competition. Thus, the CSFs can be used in conjunction with the strategic planning, implementation of a system or program, or to manage a project, process, work, or even an individual search in order to identify and monitor critical factors for each activity.

After identifying the CSFs, Gates (2010) [40] states that organizations reap benefits by choosing this method, and some of these are:

- Concentration of attention on concerns and critical factors to the initiative success, regardless of what this initiative can be;

- Possibility of integration with the strategic planning process, system or program execution, improvement or reengineering of a process, improving performance at work, or an individual search. Easiness in monitoring, and benefits are significant.

In a thorough analysis, the entire organization will be incorporated into the business or strategic planning and environmental, time, and industry categories will be present to be monitored and measured in order to identify the assertiveness of the planned actions with the actions taken, thus the association can be observed in the previous figure, contemplating the use of CSF for different actions in an organization.

\section{Results and Discussions}

\section{Application of Critical Success Factors in the Identification of Wastewater Treatment}

Applying the ambience analysis according to Howell model (2010) [42], the degree of importance given by the sector to environmental variables can be identified, which are presented in Table 4.

Howell (2010) [42] still presents that this technique can be used when there is a critical level that must be reached by the organization to be successful. This technique initially determines production or service levels that are absolutely critical to success.

By analyzing the information collected from the dairy sector and identifying the critical factors that will help in the project choice to be adopted in order to get water for reuse by a dairy sector industry, they were grouped by CSL technique such as: expansion of the national milk production in the last decade; increased concern about the environment, and standards for assessing the quality of the effluent increasingly restrictive; increasing rigor of environmental legislation and norms, with supervisory bodies such as ANA, CONAMA; increasing technological evolution, reducing life cycle of products and processes; the equipment cleaning process can take around $90 \%$ of the organic load to the effluent; and water reuse.

CSL for Industry were identified such as: the need for large volumes of water for industrial production; Pollution proportion of 1 liter milk $\times 10$ liters of effluent; management of customer requirements; contractual incentive mechanisms 
Table 4. Ambient Analysis.

\begin{tabular}{|c|c|c|c|c|c|}
\hline $\begin{array}{l}\text { Evaluate the following statements about the attributes identified in the external environment, } \\
\text { correlating the importance given by the organization based on the legend above. }\end{array}$ & $\begin{array}{l}1- \\
\text { Very low }\end{array}$ & $\begin{array}{l}2- \\
\text { LOW }\end{array}$ & $\begin{array}{l}\text { 3- } \\
\text { Medium }\end{array}$ & $\begin{array}{c}4- \\
\text { High }\end{array}$ & $\begin{array}{l}\text { 5- } \\
\text { Very high }\end{array}$ \\
\hline Expansion of the national milk production in the last decade (ECONOMY/INDUSTRY) & 0 & 0 & $35 \%$ & $54 \%$ & $12 \%$ \\
\hline $\begin{array}{l}\text { Increased concern about the environment and standards for } \\
\text { assessing the quality of increasingly restrictive effluent (SOCIAL/GOVERNMENT). }\end{array}$ & $4 \%$ & $4 \%$ & $15 \%$ & $50 \%$ & $27 \%$ \\
\hline $\begin{array}{l}\text { Investment needs of the dairy industry as for the new in plant processes related to clean } \\
\text { technologies treatment and pollution prevention tools. } \\
\text { (INDUSTRY/TECHNOLOGY/GOVERNMENT) }\end{array}$ & $4 \%$ & $4 \%$ & $38 \%$ & $35 \%$ & $19 \%$ \\
\hline $\begin{array}{l}\text { Separation process and membrane filtration as an extension of the conventional process. It is } \\
\text { used as a suggestion in reducing wastewater pollution. } \\
\text { (INDUSTRY/TECHNOLOGY/GOVERNMENT) }\end{array}$ & $4 \%$ & $15 \%$ & $27 \%$ & $42 \%$ & $12 \%$ \\
\hline $\begin{array}{l}\text { Increasing rigor of laws and environmental norms, with supervisory bodies such as ANA, } \\
\qquad \text { CONAMA, etc. (GOVERNMENT) }\end{array}$ & $4 \%$ & $4 \%$ & $23 \%$ & $63 \%$ & $8 \%$ \\
\hline $\begin{array}{l}\text { Increasing technological evolution, reducing the life cycle of products and processes. } \\
\text { (TECHNOLOGY) }\end{array}$ & $8 \%$ & $4 \%$ & $38 \%$ & $42 \%$ & $8 \%$ \\
\hline Water reuse (SOCIAL/GOVERNMENT) & $8 \%$ & $8 \%$ & $23 \%$ & $58 \%$ & $4 \%$ \\
\hline $\begin{array}{c}\text { Cultural and social evolution of the population, increasing the level of charging for goods and } \\
\text { services. (SOCIAL) }\end{array}$ & $8 \%$ & $8 \%$ & $31 \%$ & $46 \%$ & $8 \%$ \\
\hline Need of large water volumes for industrial production (INDUSTRY/TECHNOLOGY) & $8 \%$ & $4 \%$ & $23 \%$ & $54 \%$ & $12 \%$ \\
\hline Proportion of Pollution 1 liter milk $\times 10$ liters of effluent (INDUSTRY/TECHNOLOGY) & $4 \%$ & $0 \%$ & $42 \%$ & $50 \%$ & $4 \%$ \\
\hline $\begin{array}{l}\text { The cleaning process of equipment can take around } 90 \% \text { of the organic load to the effluent. } \\
\text { (INDUSTRY/TECHNOLOGY) }\end{array}$ & $0 \%$ & $4 \%$ & $35 \%$ & $50 \%$ & $12 \%$ \\
\hline Cost of technology changing (INDUSTRY/TECHNOLOGY) & $0 \%$ & $0 \%$ & $35 \%$ & $50 \%$ & $15 \%$ \\
\hline
\end{tabular}

Source: Howell model application (2010).

(organization $\times$ client) and partnership development with suppliers.

For occasional CSL were pointed out: the need for investment in the dairy industry as for in plant new processes related to clean technologies treatment and pollution prevention tools; separation processes and membrane filtration as an extension of the conventional process used as a suggestion in reducing pollution of effluents; cultural and social development of the population, increasing the level of charging for products and services; management changes; analysis of limiting factors; measurement of technical performance; relationship among lines of products/services; cost of use and disposal; effective communication; type of organizational structure; senior management support; empowerment; authority delegated to the manager; team integration; treatment of conflicts and team experience. And the CSL position: product/projects/services planning; strategic management; satisfaction with customers and flexibility.

In this way, the most suitable CSFs for strategic planning of the evaluated case industry identified in this analysis were as follows: products/projects/service planning; strategic management; satisfaction with customers and flexibility because they are directly linked to the manager's feeling on how the company would like to outperform its competitors and thus to differentiate itself in the 
market.

However, it was found out that in comparative analysis in the same situation, the sector has as differentiating factors: top management support; analysis of limiting factors (Definition of objectives and goals); provided resources; monitoring indicators; technical performance measurement; efficient communication and strategic management (link between objectives and organizational vision).

Several cases were observed and have shown that the adoption of current indicators would give assertiveness of choices to managers make decisions. With the membrane system adoption in comparison with standard systems, it is possible to achieve the following scenario for emission patterns according to the flow of effluents.

When we observe the resolution of CONSEMA (128/2006) concerning the liquid effluent discharge conditions in receiving water body, they may not exceed the shock load, and this is showed in the reference Table 5 below:

In this sense, there is the need for investment in the dairy industry as for the new in plant processes related to clean technologies treatment and pollution prevention tools. The separation processes and membrane filtration as an extension of the conventional process may be used in the reduction of effluent pollution as a suggestion. In this way, we obtain an increasing technological change, reducing the life cycle of products and processes and the reuse of water.

Regarding Internal CSFs, Gates (2010) [40] and Howell (2010) [42] relate: staff; control; risks; information and knowledge; stakeholders; planning; manager and organizational structure. Chu et al. (2012) [43] describes that the impact of team members when executed in a participatory manner, with constant interactions and individual experiences, combined with a leadership profile of managers result in cost savings and quality maintenance for organizations. In addition, Singh (2013) [44] shows that when management provides a flexible environment, likely to be built for specific projects, team members feel encouraged to add their individual experiences to the workflow, thus expanding the results and performance. Therefore, when implementing the membrane project, managers

Table 5. Emission standards in relation to the outflux.

\begin{tabular}{cccc}
\hline Outflux rate $\left(\mathrm{m}^{3} / \mathrm{d}\right)$ & $\mathrm{BOD} 5\left(\mathrm{mg} \mathrm{O}^{2} / \mathrm{L}\right)$ & $\mathrm{COD}\left(\mathrm{mgO}^{2} / \mathrm{L}\right)$ & $\mathrm{SS}(\mathrm{mg} / \mathrm{L})$ \\
\hline $\mathrm{Q}<20$ & 180 & 400 & 180 \\
$20 \leq \mathrm{Q}<100$ & 150 & 360 & 155 \\
$100 \leq \mathrm{Q}<500$ & 110 & 330 & 125 \\
$500 \leq \mathrm{Q}<1000$ & 80 & 300 & 100 \\
$1000 \leq \mathrm{Q}<3000$ & 70 & 260 & 80 \\
$3000 \leq \mathrm{Q}<7000$ & 60 & 200 & 70 \\
$7000 \leq \mathrm{Q}<10,000$ & 50 & 180 & 60 \\
$10000 \leq \mathrm{Q}$ & 40 & 150 & 50 \\
\hline
\end{tabular}

Source: CONSEMA resolution no. 128/2006. 
would be up to create opportunities for involved employees training in order to involve them in the project, observing the benefits generated, and monitoring the performance and impact on the organization and on the environment.

After the main membrane project indicators were identified in the company, the realization of performance targets was necessary, observing all aspects of the project for the organization. To Lafley and Martin (2013) [45] by agreeing with everyone involved in the project (target audience), the measured results can be shared, that is, the analysis of the results of liquid effluent could be the regulatory agencies responsibility, such as FEPAM and partnerships with stakeholders, such as public entities that would quantify benefits in the generation of wastewater, which after passing through the filtering system would present possible results of reuse both in industry and in the reintroduction of water in the environment, as can be seen in Table 6.

Singh, Kumar and Shankar (2013) [44] by approaching the project planning, highlight the need to start managing the definition of goals, and how they can be met. Thus, the size and quality of the necessary facilities to this phase are included, and different options are evaluated such as estimates of overall costs, operational performance and benefits generated by the project. Complementing the approach, Olson (2015) [4], one can identify that the relatively small costs can impact the management of a project and therefore become necessary cost-benefit analyzes, formal or informal, to accompany the initial specifications of a project. Thus, we present below the estimates of facilities and costs for wastewater treatment systems with membranes (with primary-physical processes, secondary-biochemical reactions, and tertiary-physicochemical reactions and reuse) and aerobic ponds.

To meet the recommendations of CONSEMA No 128/2006 (valid for RS state), one presents the following physicochemical treatment $+\mathrm{MF}$ at $1 \mathrm{bar}+\mathrm{RO}$ at 20 bar and costs, which are explained in Table 7 structured below, describing a company with a volume of $100 \mathrm{~m} / \mathrm{day}$, applying a permeation recycle of $\mathrm{Mi}$ crofiltration processes and reverse osmosis. With the objective of membrane lifetime projection, we used manufacturers data and wear projection of effluent referring to the dairy industry.

The structure used for making the treatment module to the dairy industry in this study is in Table 7 and observes the value of the area to be immobilized to the deposit treatment module and its respective cost.

Singh, Kumar and Shankar (2013) [44] by approaching the project planning, highlight the need to start managing the definition of goals, and how they can be met. Thus, the size and quality of the necessary facilities to this phase are included, and different options are evaluated such as estimates of overall costs, operational performance and benefits generated by the project. Complementing the approach, Olson (2015) [4], one can identify that the relatively small costs can impact the management of a project and therefore become necessary cost-benefit analyzes, formal or informal, to accompany the initial specifications of a project. Thus, we present below the estimates of facilities and costs for 
Table 6. Results of effluent analysis, combined treatment: primary and MSP in sequence with MF (122U) at 1 bar pressure, RO at 20 bar pressure, $\mathrm{RO}$ at 15 bar pressure and $\mathrm{AOP}$ with $\mathrm{H}_{2} \mathrm{O}_{2} / \mathrm{UV}$.

\begin{tabular}{|c|c|c|c|c|c|c|c|c|c|}
\hline Parameter & Effluent & $\begin{array}{l}\text { Effluent } \\
\text { primary }\end{array}$ & $\begin{array}{l}\text { Post-permeate } \\
\text { d MF (122U) }\end{array}$ & $\begin{array}{l}\text { Permeate of } \\
\text { the first RO }\end{array}$ & Ef\% & $\begin{array}{l}\text { Permeate of the } \\
\text { second RO }\end{array}$ & $\mathrm{EF}$ & $\mathrm{H}_{2} \mathrm{O}_{2} / \mathrm{U} \mathrm{V}$ & Ef \\
\hline Color (mg Pt-Co L) & $1800.00 \pm 90.1$ & $1350.00 \pm 43.3$ & $75.0+0.00$ & $0.0 \pm 0.0$ & 100 & $0.0 \pm 0.0$ & 100 & $0.0 \pm 0.0$ & 100 \\
\hline Turbidity (FAU) & $308.3 \pm 38.2$ & $158.3 \pm 38.2$ & $50.0 \pm 0.0$ & $0.0 \pm 0.0$ & 100 & $0.0 \pm 0.0$ & 100 & $0.0 \pm 0.0$ & 100 \\
\hline $\operatorname{COD}\left(\mathrm{mg} \mathrm{L}^{-1}\right)$ & $3505.5 \pm 292.7$ & $2075.0 \pm 58.9$ & $1838.9 \pm 173.5$ & $254.7 \pm 10.00$ & 92.74 & $69.2 \pm 7.0$ & 98.0 & $36.8 \pm 1.6$ & 99.0 \\
\hline TOC (mg L $\left.{ }^{-1}\right)$ & $554.8 \pm 20.1$ & $491.4 \pm 3.4$ & $463.9 \pm 6.7$ & $55.5 \pm 0.4$ & 90.0 & $31.7 \pm 0.4$ & 94.3 & $20.1 \pm 0.2$ & 96.4 \\
\hline Conductivity $\left(\mu \mathrm{Cm}^{-1}\right)$ & 2650 & 3350 & 3330 & 41.2 & 98.45 & 11.4 & 99.6 & 68.0 & 97.4 \\
\hline $\begin{array}{l}\text { Thermotolerant } \\
\text { coliforms }^{\star *}\end{array}$ & $1,600,000$ & $1,600,000$ & $1,600,000$ & 350 & 99.978 & 79 & 99.9 & $<3$ & $>99.9$ \\
\hline Total coliforms ${ }^{* *}$ & $1,600,000$ & $1,600,000$ & $1,600,000$ & 350 & 99.978 & 79 & 99.9 & $<3$ & $>99.9$ \\
\hline
\end{tabular}

Source: Bortoluzzi (2016) [25].

Table 7. Data for membrane treatment.

\begin{tabular}{|c|c|c|c|c|c|c|c|}
\hline Effluent & $\begin{array}{c}\mathrm{COD} \\
(\mathrm{mg} / \mathrm{L})\end{array}$ & $\begin{array}{c}\text { Flux } \\
\text { (L/h.m) }\end{array}$ & Outflux (L/h) & Permeate area $(\mathrm{m})$ & $\begin{array}{l}\text { Area for module } \\
\qquad(\mathrm{m})\end{array}$ & $\begin{array}{l}\text { Number of } \\
\text { modules }\end{array}$ & Cust/module (R\$) \\
\hline Net & 3505 & & 4166.67 & & & & \\
\hline Primary & 2075 & & 4166.67 & & & & \\
\hline MF Permeate & 1839 & 46.30 & 6250.00 & 135.00 & 1 & 135 & $33,750.00$ \\
\hline RO Permeate & 255 & 8.80 & $12,187.50$ & 1384.90 & 37 & 38 & $119,066.30$ \\
\hline
\end{tabular}

Source: Source: Developed by the author. ${ }^{*}$ Sizing outflow $=100 \mathrm{~m} /$ day $=4166.67 \mathrm{~L} / \mathrm{h} .{ }^{*}$ Considering 50 and $95 \%$ recycle in MF and RO permeation, respectively. ${ }^{* * *}$ Article data: "Treatment of dairy industry wastewater by reverse osmosis for water reuse" by VOURCH et al. (2008): $540 \mathrm{~m} \mathrm{RO} \mathrm{membrane} \mathrm{ar-}$ ranged for example with 18 spiral wound 8 " elements $\left(30 \mathrm{~m}^{2}\right.$ per element, 3 elements per pressure vessel, 6 vessels in parallel) ${ }^{* * * * E x p e c t e d ~ l i f e t i m e: ~} 2.5$ years for MF and 4 years for RO.

wastewater treatment systems with membranes (with primary-physical processes, secondary-biochemical reactions, and tertiary-physicochemical reactions and reuse) and aerobic ponds.

To meet the recommendations of CONSEMA No 128/2006 (valid for RS state), one presents the following physicochemical treatment $+\mathrm{MF}$ at $1 \mathrm{bar}+\mathrm{RO}$ at 20 bar and costs, which are explained in Table 8 structured below, describing a company with a volume of $100 \mathrm{~m} /$ day, applying a permeation recycle of $\mathrm{Mi}$ crofiltration processes and reverse osmosis. With the objective of membrane lifetime projection, we used manufacturers data and wear projection of effluent referring to the dairy industry.

The structure used for making the treatment module to the dairy industry in this study is in Table 8, and observes the value of the area to be immobilized to the deposit treatment module and its respective cost.

In order to identify the financial viability of membrane treatment process one compared with ponds treatment system, which is a widely-adopted procedure by dairy industries. This process requires larger immobilization area for each of its phases, thereby Table 9 describes the needed area for a dairy industry of $100 \mathrm{~m} /$ day. 
Table 8. Estimate cost for membrane module treatment.

\begin{tabular}{cc}
\hline \multicolumn{2}{c}{ Estimate costs } \\
\hline Membrane modules & $\mathrm{R} \$ 152,816.30$ \\
Pressure vessels, hydraulic plants and pumping & $\mathrm{R} \$ 60,000.00$ \\
Complete primary treatment & $\mathrm{R} \$ 45,000.00$ \\
Civilian facilities & $\mathrm{R} \$ 56,344.00$ \\
Estimated total cost & $\mathrm{R} \$ 314,160.30$ \\
\hline
\end{tabular}

Source: Source: Developed by the author $\left({ }^{\star}\right.$ Operating cost estimated at R \$ 3500.00 monthly, not counted. **Industrial basic unit cost $08 / 2016 \times 80 \mathrm{~m}$ ).

Table 9. Dimensions of modules pond steps.

\begin{tabular}{cc}
\hline Part of the pond & Dimension \\
\hline Biologic treatment pond $\mathrm{p} / 100 \mathrm{~m}^{3} / \mathrm{d}$ & $300 \mathrm{~m}$ \\
Polishing pond & $450 \mathrm{~m}$ \\
Sludge dehydration & $100 \mathrm{~m}$ \\
Pond treatment total area & $4 \mathrm{ha}$ \\
\hline
\end{tabular}

Source: Source: Developed by the author.

Table 10. Estimated costs for pond system implementation.

\begin{tabular}{cc}
\hline \multicolumn{2}{c}{ Estimate costs $^{* *}$} \\
\hline Pond areas (terrain) $)^{*}$ \\
Complete primary treatment & $\mathrm{R} \$ 200,000.00$ \\
Ponds, insulation, aeration, dehydration, hydraulic and pumping facilities & $\mathrm{R} \$ 45,000.00$ \\
Civil construction blowers (pond aeration) & $\mathrm{R} \$ 56,344.00$ \\
Estimated total cost & $\mathrm{R} \$ 509,324.00$ \\
\hline
\end{tabular}

Source: Source: Developed by the author ${ }^{*}$ considered $\mathrm{R} \$ 50.000 /$ ha. ${ }^{*}$ Estimated operational cost at R\$ 1500.00 monthly, not counted.

Costs determined for the implementation of ponds treatment take into account the total immobilized area, the necessary insulation, the equipment for aeration, dehydration, and hydraulic and pumping equipment. The cost of construction required for the viability of the works and described in Table 10 was also pointed out.

Observing Christiansen, Bosworth and Hummelmose (2000) [46] it can be clearly identified that as regards milk processing industry, the input water is mainly used for equipment cleaning areas and hygienic maintenance of the manufacturing plant and of employees. To these activities, researchers found that the water consumption rate varies in proportion to the production volume of the plant, modernization of equipment, the form of production (scale or batch) and the practices adopted by operators. However, the typical volume for reasonable and efficient water consumption of plants is 1.3 to 2.5 liters of water/kg of milk intake. 
If we observe the impact of the producing volume of a 100,000 Kg milk factory, one identifies that the current consumption is 250,000 liters of water. In addition, in many parts of Brazil, the cost of water is increasing, due to the scarcity of this asset as freshwater supply, and as the true environmental costs of its supply are taken into consideration, water is therefore an increasingly valuable asset and its efficient usage is becoming more important, and projects to reuse it in manufacturing plants or even in effluent treatment that enable the quality of water re-entry in nature become increasingly attractive and of high social impact.

\section{Conclusions}

Set robustness of analyzed critical factors, pointed to the team as a group of factors, team integration, communication and support of senior management as propelling factors for decision making:

- Identification of critical factors provides a better assertiveness in business investment;

- Critical factors present in the sector are prevalent, regardless of the organization size;

- Improved management control with the adoption of critical factors because it provides progress monitoring of each factor in each project;

- Adoption of new technologies or even productivity, which are directly related to the acceptance of the management team and further learning/adaptation of employees. It was noticed that this movement in small organizations involves all members of the company;

- Identification and approach to external stakeholders, extend the assertiveness of decision making related to investments in improvement and portfolio development;

- The membrane project becomes viable by critical factors:

1) Service of reuse water features;

2) Implementation cost;

3) Available area for equipment;

4) Absence of environmental impact;

5) Growth projection in demand for dairy products;

6) Technology update;

7) Reduction of the extracted water flow of nature or purchased by agencies.

\section{References}

[1] ANNECCHINI, K.P.V. (2005) Aproveitamento da Água da Chuva Para Fins Não Potáveis na Cidade de Vitória (ES). 150 f. Vitória, 2005. Dissertação (Mestrado em Engenharia Ambiental), Curso de Pós-Graduação em Engenharia Ambiental, Universidade Federal do Espírito Santo, Vitória.

http://portais4.ufes.br/posgrad/teses/tese_6582_VERS\%C3O\%20final\%20-\%20Karla \%20Ponzo.PRN.pdf

[2] Smithers, G. (2008) Whey and Whey Proteins-From Qutter-to-Qold. International 
Dairy Journal, 18, 695-704. https://doi.org/10.1016/j.idairyj.2008.03.008

[3] Hamerski, F. (2012) Partida de um reator anaeróbio de fluxo ascendente com manta de lodo (UASB) no tratamento de efluentes provenientes de uma indústria de laticínios.. 76 p. Dissertação (Engenharia de Processos)—Universidade Federal de Santa Maria.

[4] Olson and Wu (2010) Enterprise Risk Management. Risk Management, 12, 1-13. http://www.sprinerlink.com/index/10.1007/978-3-642-114748

[5] BASU. (2014) Managing Quality in Projects: An Empirical Study. International Journal of Project Management, 32, 178-187.

[6] Frigo, M.L. and Anderson, R.J. (2009) A Strategic Framework for Governance, Risk, and Compliance. Strategic Finance, 90, 20-61.

http://sarch.ebscohost.com/login.aspx?direct=true $\& d b=b t h \& A N=36352824 \&$ site $=e$ host-live

[7] Tarapanoff, K. and Gregolin, J.A.R. (2002) Inteligência organizacional e competitiva. Ciência da Informação, 31, 108-109.

http://www.scielo.br/scielo.php?script=sci_arttext\&pid=S0100-19652002000300012 \&lng=en\&nrm=iso\&tlng $=\mathrm{pt}$

[8] Koncagül, E., et al. (2017) Relatório Mundial das Nações Unidas sobre o Desenvolvimento dos Recursos Hídricos 2017. Programa Mundial das Nações Unidas para Avaliação do Recurso Hídricos Gabinete do Programa de Avaliação Global da Água. Divisão de Ciências Hídricas, UNESCO 06134 Colombella, Perúgia, Itália. http://unesdoc.unesco.org/images/0024/002475/247553por.pdf

[9] Gollin, J.D., Souza Filho, F.A. and da Silva, F.O.E. (2014) Considerações sobre a sustentabilidade hídrica de cisternas para captação de chuva no semiárido brasileiro. Natal: [s.n.], Simpósio de recursos hídricos do nordeste.

[10] Balannec, B., et al. (2008) Treatment of Dairy Industry Wastewater by Reverse Osmosis for Water Reuse. Desalination, 219, 190-202.

http://citeseerx.ist.psu.edu/viewdoc/download?doi=10.1.1.525.3668\&rep=rep1\&type $=\mathrm{pdf}$

[11] Strydom, J.P., Mostert, J.F. and Britz, T.J. (1997) Two-Phase Anaerobic Digestion of Different Dairy Effluents Using a Hybrid Bioreactor. Water SA, Adelaide, 23, 151-155

[12] Bharati, S.S. and Shinkar, N.P. (2013) Dairy Industry Wastewater Sources, Characteristics \& Its Effects on Environment. http://inpressco.com/wp-content/uploads/2013/11/Paper31611-1615.pdf

[13] Andrade, L.H., Mendes, F.D.S., Espindola, J.C. and Amaral, M.C.S. (2014) Nanofiltration as Tertiary Treatment for the Reuse of Dairy Wastewater Treated by Membrane Bioreactor. Separation and Purification Technology, 126, 21-29. https://doi.org/10.1016/j.seppur.2014.01.056

[14] Brião, V.B. (2007) Processos de separação por membranas para reúso de efluentes de laticínios. Tese (Doutorado em Engenharia Química), Universidade Estadual de Maringá, Maringá.

[15] Conselho Estadual do Meio Ambiente-Consema. http://www.sema.rs.gov.br/upload/arquivos/201611/30155638-resolucao-129-06-tox icidade.pdf

[16] RESOLUÇÃO CONAMA $N^{\circ}$ 430/2011: Complementa e altera a Resolução $n^{\circ}$ 357/2005. v. 1, n. 430, p. 1-9. 2014. Complementa e altera a Resolução n 357/2005. v. 1, n. 430, p. 1-9. Dispõe sobre condições e padrões de lançamento de efluentes, complementa e altera a Resolução no 357, de 17 de março de 2005, do Conselho 
Nacional do Meio Ambiente, CONAMA, Data da legislação: 13/05/2011, Publicação DOU n ${ }^{\circ}$ 92, de 16/05/2011, pág. 89.

http://www.mma.gov.br/port/conama/legiabre.cfm?codlegi=646

[17] Britz, T.J., Lamprecht, C. and Sigge, G.O. (2008) Dealing with Environmental Issues. In: Britz, T.J. and Robinson, R.K., Eds., Advanced Dairy Science and Technology, Blackwell Publishing Ltd., Oxford, 35-75.

https://doi.org/10.1002/9780470697634.ch7

[18] Magno, P.S.L. and Oliveira, J.R. (2009) Tratamento de efluentes através de lagoas de estabilização: comparação entre eficiência teórica e eficiência real. XV Congresso Brasileiro de Aguas Subterrâneas.

https://aguassubterraneas.abas.org/asubterraneas/article/view/21951/14320

[19] Braile, P.M. and Cavalcanti, J.E.W.A. (1993) Manual de tratamento de águas residuária industriais. São Paulo.

[20] Peirano, M.M.F. (1995) Tratamento de efluentes em laticínios. Revista Leite e Derivados, No. 21.

[21] Cammarota, M.C. and Freire, D.M.G. (2006) A Review on Hydrolytic Enzymes in the Treatment of Wastewater with High Oil and Grease Content. Bioresource Technology, 97, 2195-2210. https://doi.org/10.1016/j.biortech.2006.02.030

[22] Machado, R.M.G., et al. (2002) Controle ambiental nas pequenas e médias indústrias de laticínios. 1st Edition, Segrac, Belo Horizonte.

[23] MORAIS (2005) Estudo da potencialidade de processos oxidativos avançados, isolados e integrados com processos biológicos tradicionais, para tratamento de chorume de aterro sanitário. Tese (Pós-Graduação em Química), Universidade Federal do Paraná, Curitiba, 207 p. http://acervodigital.ufpr.br/bitstream/handle/1884/3523/TESEDOUTPPGQJOSMA RIALOPESDEMORAIS.pdf?sequence $=1$

[24] Daufin, G., et al. (2001) Recent and Emerging Applications of Membrane Processes in the Food and Dairy Industry. Food and Bioproducts Processing, 79, 89-102.

[25] Bortoluzzi (2016) Processos avançados de tratamento de efluentes líquidos da indústria de soro visando a obtenção de água para reuso. Tese (Engenharia de Alimentos), Universidade Regional Integrada do Alto Uruguai e das Missões, 133 p.

[26] Reis, R.V. and Zydney, A. (2001) High Performance Tangential Flow Filtration: Membrane Separations in Biotechnology. 2nd Edition, W.K. Wang, Marcel Dekker, Inc.

[27] Habert, A.C., Borges, C.P. and Nobrega, R. (2006) Processos de Separação por Membranas. Série Escola Piloto em Engenharia Química.

[28] Dekker, M., Maroulis, Z.B. and Saravacos, G.D. (2003) Food Process Design. New York.

[29] Borges, C.P., Nobrega, R. and Habert, A.C. (1997) Processos de Separação com Membranas. In: Escola Piloto em Engenharia Química.

[30] Girard, B., Fukumoto, L.R. and Koseoglu, S.S. (2000) Membrane Processing of Fruit Juices and Beverages: A Review. Critical Reviews in Biotechnology, 20, 109-175. https://doi.org/10.1080/07388550008984168

[31] Schneider, R.P. and Tsutiya, M.T. (2001) Membranas filtrantes para o tratamento de água, esgoto e água de reuso. ABES, São Paulo.

[32] Walstra, P., Geurts, T.J., Noomen, A., Jellema, A., and Van Boekel, M.A.J.S. (year) Dairy Technology: Principles of Milk Properties and Processes.

http://197.14.51.10:81/pmb/AGROALIMENTAIRE/Lait\%20et\%20derives/Dairy\%20 
Science\%20and\%20Technology\%20(CRC\%202005).pdf

[33] Coutinho, C.M., et al. (2009) State of Art of the Application of Membrane Technology to Vegetable Oils: A Review. Food Research International, 42, 536-550. https://doi.org/10.1016/j.foodres.2009.02.010

[34] Pabby, A.K., Rizvi, S.S.H. and Sastre, A.M. (2009) Handbook of Membrane Separations: Chemical, Pharmaceutical, Food, and Biotechnological Applications. CRC PRESS, New York.

[35] Mulder, M. (2000) Basic Principles of Membranes Technology. Kluwer Academic, Boston.

[36] Macedo, M.M.G., et al. (2011) Cálculo da rugosidade e dimensão fractal de material nano-estruturado. Rio de Janeiro.

[37] Naisbitt, J. (1999) Paradoxo global. Campus, Rio de Janeiro.

[38] Daniel, D.R. (1961) Management Information Crisis. Harvard Business Review, 39, 111-121.

[39] Rockart, J.F. (1982) The Changing Role of the Information Systems Executive: A Critical Success Factors Perspective. Sloan Management Review, 24, 3-13.

[40] Gates, L.P. (2010) Strategic Planning with Critical Success Factors and Future Scenarios: An Integrated Strategic Planning Framework. Software Engineering Institute. https://doi.org/10.21236/ADA532574

[41] Finney, S. and Corbett, M. (2007) ERP Implementation: A Compilation and Analysis of Critical Success Factors. Business Process Management Journal, 13, 329-347. https://doi.org/10.1108/14637150710752272

[42] Howell, T.M. (2010) Critical Success Factors Simplified: Implementing the powerful drivers of dramatic business Improvement. CRC Press, New York.

[43] Li, J., Chu, C.W.L., Wang, X.R., Zhu, H., Tang, G.Y. and Chen, Y.Y. (2012) Symbiotic Ownership, Cultural Alignment, and Firm Performance: A Test among International Strategic Alliances. International Business Review, 21, 987-997.

https://doi.org/10.1016/j.ibusrev.2011.11.004

[44] Singh, R.K., Kumar, R. and Shankar, R. (2012) Supply Chain Management in SMEs: A Case Study. International Journal of Manufacturing Research, 7, 165-180. https://doi.org/10.1504/IJMR.2012.046801

[45] Lafley, A.G. and Martin, R.L. (2013) Playing to Win: How Strategy Really Works. Harvard Business Review Press, Boston.

[46] Bosworth, M.E., Hummelmose, B. and Christiansen, K. (2000) Cleaner Production Assessment of Dairy Processing. Danish Environmental Protection Agency. 